\title{
Effect of Plant Growth Regulators on Growth, Yield and Flower Quality of Gerbera (Gerbera jamesonii L.) cv. Pink Elegance under Naturally Ventilated Polyhouse (NVPH)
}

\author{
Zosser Cherik N. Sangma*, Devi Singh and Urfi Fatmi
}

Department of Horticulture (Floriculture and Landscaping), Sam Higginbottom University of Agriculture, Technology and Sciences, Allahabad, 211007 (U.P), India

*Corresponding author

\begin{tabular}{|c|c|}
\hline \multicolumn{2}{|r|}{ A B S T R A C T } \\
\hline & \multirow{11}{*}{$\begin{array}{l}\text { An experiment was conducted to evaluate the effect of plant growth regulators on growth, } \\
\text { yield, and flower quality of gerbera (Gerbera jamesonii } \mathrm{L} \text {.) cv. Pink Elegance under } \\
\text { naturally ventilated polyhouse in the Department of Horticulture, Sam Higginbottom } \\
\text { University of Agriculture, Technology and Sciences, Allahabad, U.P. during winter season } \\
2016 \text { to } 2017 \text {. The experiment was laid out in Randomized Block Design with three } \\
\text { replications and nine treatments. In this study gerbera plants were sprayed four times with } \\
50,100,150,200 \mathrm{ppm} \text { ofGA } \mathrm{A}_{3} \text { and } 50,100,150,200 \mathrm{ppm} \text { of NAA along with control (water } \\
\text { spray). The results of five months experimentation revealed that maximum plant height } \\
(45.27 \mathrm{~cm}) \text {, number of leaves per plant }(27.40) \text {, plant spread }(54.17 \mathrm{~cm}) \text {, days to first } \\
\text { flower bud emergence or earliness ( } 39.90 \text { days), flower diameter }(14.74 \mathrm{~cm}) \text {, stalk length } \\
(52.90 \mathrm{~cm}) \text {, stalk girth }(2.57 \mathrm{~cm}) \text {,number of flowers per plant }(12.50) \text { and number of cut } \\
\text { flowers per treatment }(112.50) \text { were produced in treatment }\left(\mathrm{T}_{3}\right) \mathrm{GA}_{3} \text { at } 150 \mathrm{ppm} \text {. Whereas } \\
\text { maximum vase life of flower }(14.80 \text { days) and number of suckers per plant }(6.10) \text { were } \\
\text { produced by treatment }\left(\mathrm{T}_{2}\right) \mathrm{GA}_{3} \text { at } 100 \text { ppm. } \mathrm{T}_{3} \text { was found to be the best treatment for good } \\
\text { vegetative as well as reproductive growth. }\end{array}$} \\
\hline Keywords & \\
\hline Gerbera, Plant & \\
\hline growth regulators, & \\
\hline & \\
\hline & \\
\hline Article Info & \\
\hline Accepted: & \\
\hline 07 September 2017 & \\
\hline & \\
\hline & \\
\hline
\end{tabular}

\section{Introduction}

Gerbera (Gerbera jamesonii L) belongs to family Asteraceae and is native to tropical Asia and Africa. Gerbera came into dictionary of floriculture after it was discovered by preLinnean botanist, Gronovious but it received its fortunate name in honour of German naturalist, 'Traugott Gerber' who travelled in Russia in 1743.

Gerbera is an important cut flower having single and double flowers. It is used in fresh and dry flower arrangement, floral decoration, exhibition and in high class bouquet.
The colour variation, their meaning, size of flowers, long lasting behaviour and wide adaptability for culture made gerbera a flower of choice for cultivation in India. The daisy like flowers are available in wide range of colours including yellow, red, orange, cream, white, pink, brick red, scarlet, salmon peach, maroon and various other intermediate shades.

Gerbera is a dwarf herbaceous perennial and grows in clump with solitary flower heads on a long slender stalk, which grows well above 
the foliage. In protected structures (polyhouse and shade house), they grow faster and produce larger and greener leaves with high dry matter content.

Commercial production of gerbera as cut flower has a great demand in both national as well as international markets. The demand of cut flower production in the country is increasing at a rapid pace, especially in winter when very few annuals bloom during that period. The use of plant growth regulators has brought a revolution in the floriculture industry and has been found to be of great significance in the commercial cultivation of many ornamental crops. Plant growth regulators play important role in cut flowers are applied to plants to regulate plant development and to stimulate a desired growth response.

Growth regulators are used to overcome the factors limiting the growth and yield to harness maximum benefit. It is also observed that foliar application of growth regulators stimulates flowering to get maximum yield. In gerbera it stimulates cellular elongations, so without them, cells do not elongate much and plants do not grow tall.

Plant growth regulators also influence the vegetative growth and flowering in gerbera. Thus, keeping in view the potentialities of growth regulators like gibberellic acid and naphthalene acetic acid the present study was undertaken to find out the suitable concentration of $\mathrm{GA}_{3}$ and NAA for better growth, yield and quality of gerbera under naturally ventilated polyhouse.

\section{Materials and Methods}

The experiment was conducted during winter season 2016 to 2017 at the Department of Horticulture, Sam Higginbottom University of Agriculture Technology and Sciences,
Allahabad, UP. The experimental site is situated at the latitude of $20^{\circ}$ and $15^{\circ}$ North and longitude of $60^{\circ}$ East and at altitude of 98 meters above mean sea level (MSL).The soil of experimental site was sandy loam in texture with $\mathrm{pH} 7.3$, E.C of $0.18 \mathrm{dSm}^{-1}$ and carbon of $40 \%$. The available nitrogen, phosphorus and potassium contents were 205.2, 22.5 and $280 \mathrm{~kg} \mathrm{ha}^{-1}$ respectively.

The experiment was laid out in Randomized Block Design with three replications and nine treatments. The seedlings of cv. Pink Elegance with 4-5 leaves were planted in raised bed on $7^{\text {th }}$ November 2016 at the spacing of $30 \mathrm{~cm} \times 30 \mathrm{~cm}$ without burying the crown. The two regulators namely gibberellic acid and naphthalene acetic acid were taken. The details of the treatment combination are as follows:

$\mathrm{T}_{0}$ - Control (Water spray)

$\mathrm{T}_{1}-\mathrm{GA}_{3} @ 50 \mathrm{ppm}$

$\mathrm{T}_{2}-\mathrm{GA}_{3} @ 100 \mathrm{ppm}$

$\mathrm{T}_{3}-\mathrm{GA}_{3} @ 150 \mathrm{ppm}$

$\mathrm{T}_{4}-\mathrm{GA}_{3} @ 200 \mathrm{ppm}$

$\mathrm{T}_{5}$ - NAA@ @ 50ppm

T 6 - NAA@100ppm

$\mathrm{T}_{7}$ - NAA@150ppm

T8 - NAA @200ppm

This growth regulator was given through foliar spray. They are soluble in ethyl alcohol and then diluted in water. It was applied after one month of transplanting and subsequently at 15 days intervals.

All the cultural operations were done as per the need of crop. The data were recorded on plant height, number of leaves, plant spread, days of first flower bud emergence or earliness, flower diameter, stalk length, stalk girth, vase life of flower, number of suckers per plant, number of cut flowers per plant and number of cut flower per treatment were taken. 


\section{Results and Discussion}

\section{Growth parameters}

The data on growth parameters presented in Table 1 show that maximum plant height $(45.27 \mathrm{~cm})$, number of leaves $(27.40)$ and plant spread $(54.17 \mathrm{~cm})$ was found to be in treatment $\mathrm{T}_{3}\left(\mathrm{GA}_{3} @ 150 \mathrm{ppm}\right)$. While minimum plant height $(29.57 \mathrm{~cm})$, number of leaves $(22.57)$ and plant spread $(35.77 \mathrm{~cm})$ was recorded in treatment $\mathrm{T}_{0}$ (control). Significantly maximum plant height, number of leaves and plant spread may be due to gibberellic acid which has resulted in cell division and cell elongation resulting in enhanced vegetative growth. Similar observation in maximum plant height were also obtained by Dalal et al., (2009) and maximum plant spread at 150ppm were also obtained by Patra et al., (2015) in gerbera (Fig. 1).

\section{Qualitative parameters}

The data on qualitative parameters presented in Table 2 show that minimum number of days for first flower bud emergence or earliness which took (39.90 days) was found in $T_{3}$ (GA 3 @150ppm) whereas $\mathrm{T}_{0}$ (control) took maximum number of days (54.23 days) to produce visible flower bud. Maximum flower diameter $(14.74 \mathrm{~cm})$, maximum stalk length $(52.90 \mathrm{~cm})$, maximum stalk girth $(2.57 \mathrm{~cm})$, was recorded in $\mathrm{T}_{3}$ (GA3@150ppm). While maximum vase life of flower (14.80days) and maximum number of suckers per plant (6.10) were found in treatment $\mathrm{T}_{2}$ (GA3@100ppm).

However, minimum flower diameter $(12.03 \mathrm{~cm})$, minimum stalk length $(48.87 \mathrm{~cm})$, minimum stalk girth $(1.77 \mathrm{~cm})$, minimum vase life of flower (9.76days) and minimum numbers of suckers (3.23) were found lowest in $\mathrm{T}_{0}$ (control). This parameter is due to fact that $\mathrm{GA}_{3}$ increased cell division and cell elongation. It also accumulates more carbohydrate in plant body which leads to early flower bud initiation as well as bud opening, later which results in lengthening of flowering span. The plants receiving required gibberellic acid in an optimum proportion could have results in flowering quality by increasing number of cells. The results of minimum days for first flower initiation (108.33 days), maximum flower diameter $(8.76 \mathrm{~cm})$, flower weight $(5.93 \mathrm{~g})$ and shelf life of flowers (8.00 days) were obtained in the treatment $\mathrm{GA}_{3}$ at $150 \mathrm{ppm}$ obtained by Patel et al., (2010) in chrysanthemum.GA 3 also produced the higher number of sucker, foliar application of $150 \mathrm{ppm} \mathrm{GA}_{3}$ was the best for obtaining better growth of plants, maximum number of cut blooms with longer stalk as well as bigger flower size obtained by Sharifuzzaman et al., (2011) in chrysanthemum. Chauhan et al., (2014) observed that $\mathrm{GA}_{3}$ at 150 ppm showed lowest number of days to the appearance of first flower bud (50.98days) and diameter of flower $(11.37 \mathrm{~cm})$ in gerbera. Salem et al., (2016) reported that in gerbera maximum yield and quality parameters (number of flowers per plant, stalk length, flower bud diameter and stalk diameter) and days to flower bud emergence and days to first flowering were observed with treatment of $\mathrm{GA}_{3}$ at $150 \mathrm{ppm}$ (Fig. 2).

\section{Yield parameters}

The data on yield parameters presented in Table 3 show that the maximum number of cut flowers per plant (12.50), number of cut flowers per treatment (112.50) was recorded to be in treatment $\mathrm{T}_{3}$ (GA3@150ppm). Minimum number of cut flowers per plant (9.43), number of cut flowers per treatment (84.87) was recorded in treatment $\left(\mathrm{T}_{0}\right)$ control. Significantly maximum number of cut flowers per plant, number of cut flowers per treatment (Fig. 3). 
Table.1 Effect of plant growth regulators on growth parameters of gerbera

(Gerbera jamesonii L.) cv. Pink Elegance

\begin{tabular}{|c|c|c|c|}
\hline Treatments & Plant height $(\mathbf{c m})$ & Number of leaves & Plant spread (cm) \\
\hline $\mathbf{T}_{\mathbf{0}}$ & 29.57 & 22.57 & 35.77 \\
\hline $\mathbf{T}_{\mathbf{1}}$ & 37.43 & 25.23 & 47.93 \\
\hline $\mathbf{T}_{\mathbf{2}}$ & 44.50 & 26.53 & 53.27 \\
\hline $\mathbf{T}_{\mathbf{3}}$ & 45.27 & 27.40 & 54.17 \\
\hline $\mathbf{T}_{\mathbf{4}}$ & 41.93 & 26.77 & 52.20 \\
\hline $\mathbf{T}_{\mathbf{5}}$ & 33.60 & 24.13 & 45.70 \\
\hline $\mathbf{T}_{\mathbf{6}}$ & 35.77 & 24.53 & 49.83 \\
\hline $\mathbf{T}_{\mathbf{7}}$ & 37.17 & 24.90 & 49.50 \\
\hline $\mathbf{T}_{\mathbf{8}}$ & 40.53 & 25.70 & 52.63 \\
\hline Mean & 38.42 & 27.89 & 49.00 \\
\hline S. $\mathbf{E d}$ ( $\mathbf{(})$ & 0.83 & 0.52 & 0.68 \\
\hline C. $\mathbf{D}$. at 5 \% & 1.75 & 1.03 & 1.44 \\
\hline
\end{tabular}

Table.2 Effect of plant growth regulators on qualitative parameters of gerbera (Gerbera jamesonii L.) cv. Pink Elegance

\begin{tabular}{|c|c|c|c|c|c|c|}
\hline Treatments & $\begin{array}{c}\text { Days of first flower } \\
\text { bud emergence or } \\
\text { earliness }\end{array}$ & $\begin{array}{c}\text { Flower } \\
\text { diameter } \\
(\mathbf{c m})\end{array}$ & $\begin{array}{c}\text { Stalk length } \\
\mathbf{( c m )}\end{array}$ & $\begin{array}{c}\text { Stalk } \\
\text { girth }(\mathbf{c m})\end{array}$ & $\begin{array}{c}\text { Vase life of } \\
\text { flower (days) }\end{array}$ & $\begin{array}{c}\text { Number of } \\
\text { suckers per } \\
\text { plant }\end{array}$ \\
\hline $\mathbf{T}_{\mathbf{0}}$ & 54.23 & 12.03 & 48.87 & 1.77 & 9.67 & 3.23 \\
\hline $\mathbf{T}_{\mathbf{1}}$ & 45.87 & 13.65 & 51.13 & 2.04 & 12.10 & 4.40 \\
\hline $\mathbf{T}_{\mathbf{2}}$ & 40.43 & 14.49 & 52.17 & 2.52 & 14.80 & 6.10 \\
\hline $\mathbf{T}_{\mathbf{3}}$ & 39.90 & 14.74 & 52.90 & 2.57 & 14.17 & 5.33 \\
\hline $\mathbf{T}_{\mathbf{4}}$ & 45.73 & 14.27 & 51.80 & 2.31 & 13.53 & 5.17 \\
\hline $\mathbf{T}_{\mathbf{5}}$ & 50.20 & 13.24 & 50.47 & 1.80 & 11.87 & 4.13 \\
\hline $\mathbf{T}_{\mathbf{6}}$ & 49.83 & 13.36 & 51.27 & 2.03 & 11.93 & 4.23 \\
\hline $\mathbf{T}_{\mathbf{7}}$ & 46.67 & 14.15 & 51.73 & 2.31 & 12.07 & 4.20 \\
\hline $\mathbf{T}_{\mathbf{8}}$ & 40.83 & 14.23 & 51.87 & 2.43 & 12.40 & 5.07 \\
\hline Mean & 45.97 & 13.79 & 51.36 & 2.20 & 12.50 & 4.65 \\
\hline S. Ed. $\mathbf{(})$ & 0.81 & 0.30 & 0.36 & 0.20 & 0.38 & 0.30 \\
\hline C. D. at 5 \% & 1.63 & 0.64 & 0.77 & 0.42 & 0.82 & 0.63 \\
\hline
\end{tabular}

Table.3 Effect of plant growth regulators on yield parameters of gerbera

(Gerbera jamesonii L.) cv. Pink Elegance

\begin{tabular}{|c|c|c|}
\hline Treatments & Number of cut flowers per plant & Number of cut flowers per treatment \\
\hline $\mathbf{T}_{\mathbf{0}}$ & 9.43 & 84.87 \\
\hline $\mathbf{T}_{\mathbf{1}}$ & 10.27 & 92.43 \\
\hline $\mathbf{T}_{\mathbf{2}}$ & 11.53 & 103.77 \\
\hline $\mathbf{T}_{\mathbf{3}}$ & 12.50 & 112.50 \\
\hline $\mathbf{T}_{\mathbf{4}}$ & 10.83 & 97.47 \\
\hline $\mathbf{T}_{\mathbf{5}}$ & 10.13 & 91.17 \\
\hline $\mathbf{T}_{\mathbf{6}}$ & 10.20 & 91.80 \\
\hline $\mathbf{T}_{\mathbf{7}}$ & 10.43 & 93.83 \\
\hline $\mathbf{T}_{\mathbf{8}}$ & 11.13 & 100.17 \\
\hline Mean & 10.72 & 96.44 \\
\hline S. Ed. $\mathbf{\pm})$ & 0.22 & 0.57 \\
\hline C. D. at 5 \% & 0.46 & 1.21 \\
\hline
\end{tabular}


Table.4 Economics of gerbera as influenced by different treatments

\begin{tabular}{|c|c|c|c|c|c|}
\hline Treatments & $\begin{array}{l}\text { Total cost of } \\
\text { cultivation }(\mathbf{R s})\end{array}$ & $\begin{array}{l}\text { Flower } \\
\text { yield/200m }\end{array}$ & $\begin{array}{l}\text { Gross return } \\
\text { (Rs.) }\end{array}$ & Net return (Rs.) & $\begin{array}{l}\text { Benefit Cost } \\
\text { Ratio }\end{array}$ \\
\hline $\mathrm{T}_{0}$ & 41,427 & 16973.33 & 101839.98 & 60412.98 & 2.46 \\
\hline $\mathrm{T}_{1}$ & 41,445 & 18486.67 & 110920.02 & 69475.02 & 2.67 \\
\hline $\mathrm{T}_{2}$ & 41,463 & 20753.33 & 124519.98 & 83056.98 & 3.00 \\
\hline $\mathrm{T}_{3}$ & 41,481 & 22500.00 & 135000.00 & 93519.00 & 3.25 \\
\hline $\mathrm{T}_{4}$ & 41,499 & 19493.33 & 116959.98 & 75460.98 & 2.82 \\
\hline $\mathrm{T}_{5}$ & 41,681 & 18233.33 & 109399.98 & 67718.98 & 2.42 \\
\hline $\mathrm{T}_{6}$ & 41,877 & 18360.00 & 110160.00 & 68283.00 & 2.63 \\
\hline $\mathrm{T}_{7}$ & 42,102 & 18766.67 & 112600.02 & 70498.02 & 2.67 \\
\hline $\mathrm{T}_{8}$ & 42,327 & 20033.33 & 120199.98 & 77872.98 & 2.84 \\
\hline
\end{tabular}

Market price of gerbera cut flower grown under polyhouse at Allahabad Rs. 6/stalk.

Fig.1 Effect of plant growth regulators on growth parameters of gerbera

(Gerbera jamesonii L.) cv. Pink Elegance

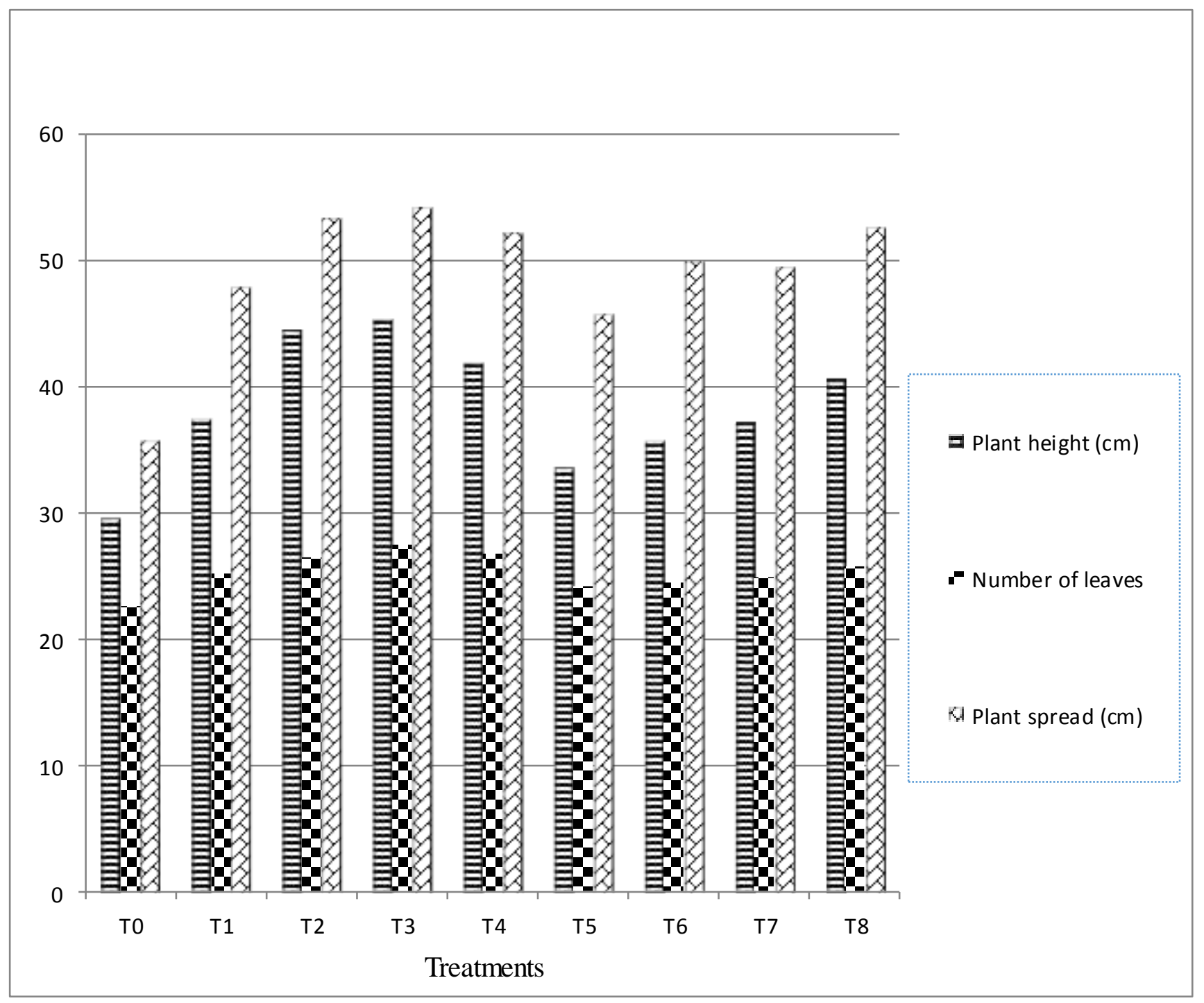


Fig.2 Effect of plant growth regulators on qualitative parameters of gerbera (Gerbera jamesonii L.) cv. Pink Elegance

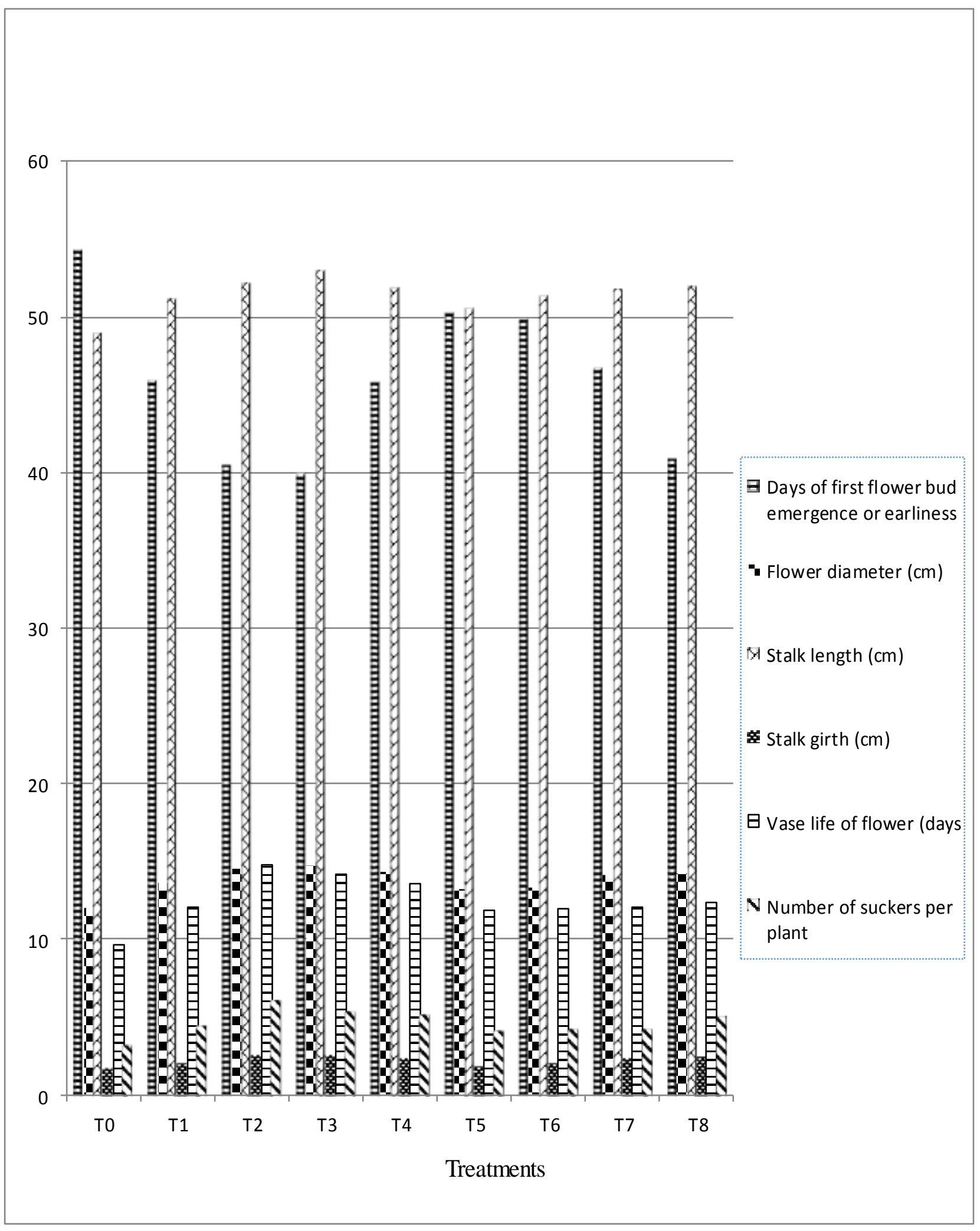


Fig.3 Effect of plant growth regulators on yield parameters of gerbera (Gerbera jamesonii L.) cv. Pink Elegance

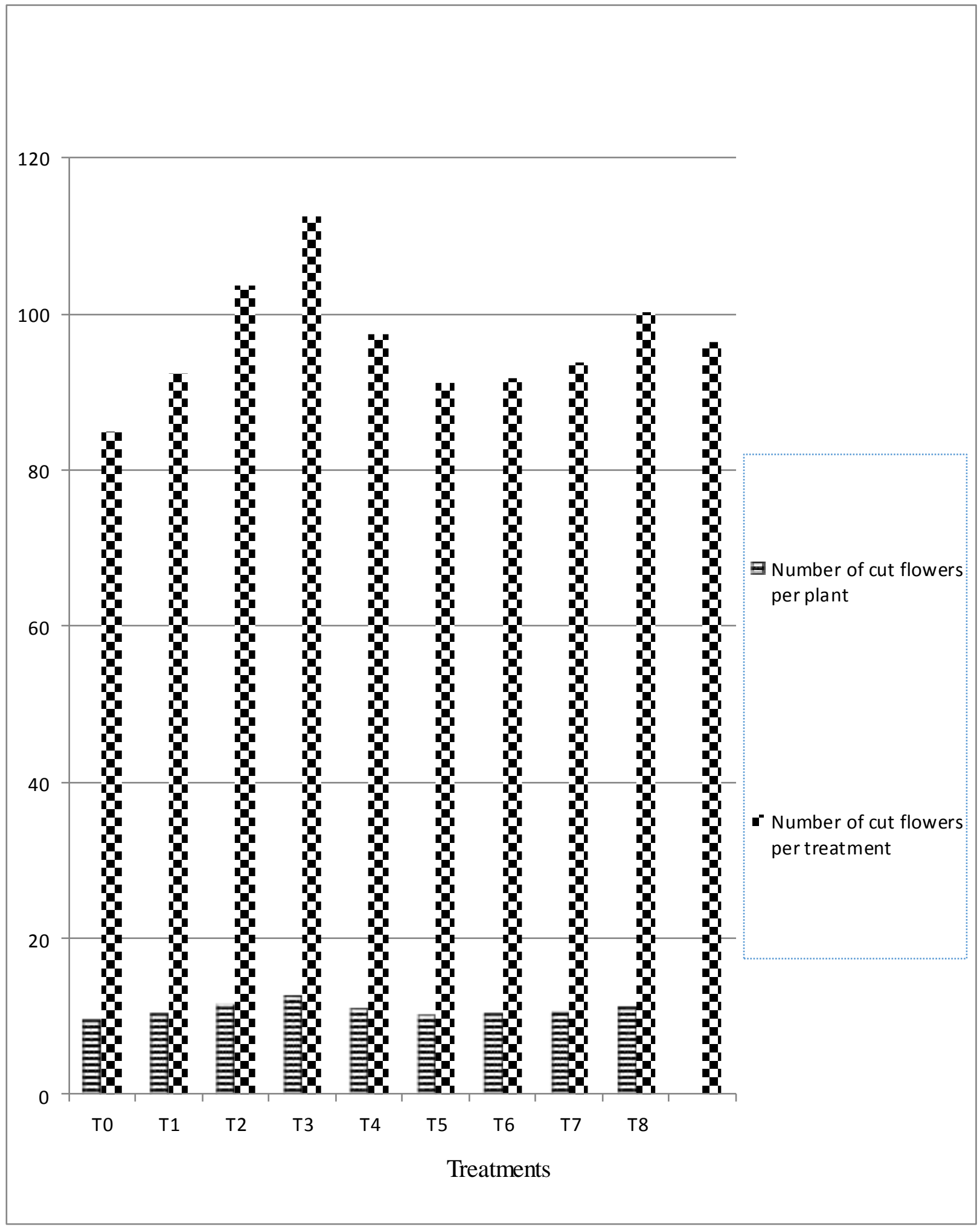


The increase in yield of flowers might be due fact that, gibberellic acid treated plants produced more number of leaves which might have resulted in production and accumulation of more photosynthates that were diverted to the sink resulting in more number of flowers. These results are in close conformity with the findings of Dalal et al., (2009) in gerbera and Patel et al., (2010) in chrysanthemum.

\section{Economics}

The economics feasibility of each treatment regarding the gross income, total cost of cultivation, net income and benefit cost ratio have been work out and shown in Table 4 . The data presented in the table shows maximum yield $\left(22500.00 / 200 \mathrm{~m}^{2}\right)$, gross income (Rs135000.00), net income (Rs.93519.00) and benefit cost ratio (3.25). Minimum yield $\left(16973.33 / 200 \mathrm{~m}^{2}\right)$, gross income (Rs101839.98), net income (Rs.60412.98) and benefit cost ratio (2.46).

Based on the above discussions, it can be concluded that $\left(\mathrm{T}_{3}\right) \mathrm{GA}_{3} @ 150 \mathrm{ppm}$ treatment combination was found to be the best treatment as compared to others and significantly gave higher yield of gerbera and is effective for enhancing plant growth, flower quality and yield of gerbera. As the study was under taken only for one season, it needs further confirmation by conducting more trials.

\section{References}

Chauhan, R.V., Kav, K.P., Babariya, V.J., Pansuria, P.B. and Savaliya, A.B. (2014) Effect of gibberellic acid on flowering and cut flower yield in Gerbera under protected condition. Asian Journal of Horticulture 9 (2):404407.

Dalal, S.R., Somavanshi, A.V. and Karale, G.D. (2009) Effect of gibberellic acid on growth, flowering, yield and quality of Gerbera under polyhouse condition; International journal of agriculture sciences 5(2): 355-356.

Emongor, V.E. (2004) Effect of gibberellic acid on post-harvest quality and vase life of Gerbera cut flowers (Gerbera jamesonii), Journal of agronomy 3(3): 191-195.

Girisha, R., Shirol,A. M., Reddy, B. S., Kulkarni, B.S., Patil, S. and Murthy, G.H.K., (2012) Growth, quality and yield characteristics of daisy (Aster amellus l.) cultivar Dwarf Pink as influenced by different plant growth regulator; Karnataka J.Agric.Sci., 25(1) : 163-165.

Jamil, M.K., Rahman, M.M., Hosssain, M.M., Hosssain, M.T. and Karim, A. J. M. S. (2015) Effect of plant growth regulators on flowering and bulb production of Hippeastrum (Hippeastrum hybridum Hort.). Bangladesh J. Agril.Res. 40(4): 591-600.

Kumar, M., Singh, A. K. and Kumar A. (2014) Effect of plant growth regulators on flowering and yield attribiutes of African marigold (Tagetes erecta L.) cv. Pusanarangigainda, Plant Archives 14(1): 363-365.

Kumar, R., Ahmed, N., Singh, D.B., Sharma, O.C., Lal, S., and Salmani, M.M. (2013) Enhancing blooming period and propagation coefficient of Tulip (TulipagesnerianaL.) using growth regulators. African Journal of Biotechnology 12(2):168-174.

Padaganur, V.G., Monakshi, A.N., and Patel, V.S. (2005) Effect of plant growth regulators on growth and yield of Tuberose cv. Single, Karnataka J.Agric.Sci., 18(2):469-473.

Palei, S., Das, A.K. and Dash, D.K. (2016). Effect of plant growth regulators on flowering and yield attributes of African marigold (Tagetes erecta L.) cv. 
Pusanarangigainda, International education and research journal, 2(6):2454-9916.

Patil, D., Chopde, N., Lokhande, S., and Bhande, M.H. (2016) Studies on response of African marigold to plant growth regulators for seed production.Plant Archives 16 (1): 423425.

Patra, S.K., Beura, S., and Shasani, T. (2015) Efficacy of $\mathrm{GA}_{3}$ on growth and flowering regulation of in vitro raised hybrid Gerbera under shade net. Agric. Sci. Digest., 35 (3):173-177.

Sajid, M., Amin, N., Ahmad, H., and Khan, K. (2016) Effect of gibberellic acid on enhancing flowering time in Chrysanthemum morifolium; Pak.J. Bot., 48(2): 477-483.

Salem, R.A.A., Saravanan, S., and Prasad V.M. (2016) Effect of gibberellic acid spraying on yield and flowers of Gerbera (Gerbera jamesonii) c.v Dennis. International journal of scientific research5 (3):2277-8179.

Sharifuzzaman, S.M., Ara, K.A., Rahman,
M.H., Kabir, K. and Talukdar, M.B., (2011) Effect of $\mathrm{Ga}_{3}, \mathrm{CCC}$ and $\mathrm{MH}$ on vegetative growth, flower yield and quality of Chrysanthemum. Int. J. Expt. Agric. 2(1):17-20.

Sujatha, A. N., Singh, V. and Sharma, T. V. R. S. (2002) Effect of plant growth regulators on yield and quality of Gerbera under Bay island condition. Indian J. Hort, 59(1):100-105.

Uddin, A.F.M.J., Mehraj, H., Taufique, T., Ona, A. F. and Parvin, S. (2014) Foliar Application of gibberellic acid on growth and flowering of Gerbera cultivars. Journal of Bioscience and Agriculture Research,2(1): 52-58.

Uddin, M.S., Hossain, A.V.M.S., Normania, O., Boyce, A.N. and Moneruzzaman, K.M. (2009) Effect of Naphthalene acetic acid and Gibberellic acid in prolonging bract longetivity and delaying discoloration of Bougainvillea spectabillis, J. of Biotechnology8 (3): 3434-350.

\section{How to cite this article:}

Zosser Cherik N. Sangma, Devi Singh and Urfi Fatmi. 2017. Effect of Plant Growth Regulators on Growth, Yield and Flower Quality of Gerbera (Gerbera jamesonii L.) cv. Pink Elegance under Naturally Ventilated Polyhouse (NVPH). Int.J.Curr.Microbiol.App.Sci. 6(10): 468-476. doi: https://doi.org/10.20546/ijcmas.2017.610.057 